\title{
Histological Investigations at an Intestinal Level on Laying Quails Fed with Fodders Supplemented with Different Additives (Sel-Plex, Actigen and Bio-Mos)
}

\author{
Teodor I. MĂLDĂRĂŞANU*1), Aurel ŞARA ${ }^{1)}$, Călina CREȚA $^{2)}$, Mihai BENȚEA ${ }^{1)}$ \\ ${ }^{1)}$ University of Agricultural Sciences and Veterinary Medicine, Faculty of Animal Science \\ and Biotechnologies, 3-5 Mănăştur Street, 400372 Cluj-Napoca, Romania \\ ${ }^{2)}$ National Institute of Public Health, Territorial Center of Public Health Cluj, 6 Pasteur Street, \\ 400349 Cluj-Napoca, Romania \\ *Corresponding author, email: maldarasanu_teodor@yahoo.com
}

Bulletin UASVM Animal Science and Biotechnologies 72(1) / 2015

Print ISSN 1843-5262; Electronic ISSN 1843-536X

DOI:10.15835/buasvmcn-asb:10442

\begin{abstract}
The aim of this paper was to observe and highlight the possible influence of prebiotics (BioMos and Actigen) and organic Selenium (Sel-Plex), administered in the feeds of laying quails, on the intestinal mucosa and the impact it has on the production and consumption performances of the laying quails.

The research has been carried out on 132 laying quails, assigned to 4 groups, each group consisting of 33 birds; a control group fed with combined fodder without any additives and 3 experimental groups fed with additives supplemented fodders -Actigen (0.08\%) in experimental group 1, Bio-Mos $(0.12 \%)$ in experimental group 2 and organic Selenium (Sel-Plex -0.04\%) in experimental group 3. The experimental period was 26 weeks (from the age of 6 weeks until the age of 32 weeks). The lying quails were individually weighted at the beginning, at the middle and at the end of the experimental period.

The main histological investigations that were carried out at the end of the experimental period consisted of the determination of the villi height, microvilli height and the subsequent intestinal absorption surface; also the body mass evolution, laying intensity and feed conversion were monitored. The birds in all the groups were kept in the same rearing conditions, throughout the entire experimental period.

The recorded results confirm the positive influence of the used prebiotics (Bio-Mos and Actigen) and organic Selenium (Sel-Plex) on the intestinal mucosa by increasing the nutrient absorption surface thus explaining the improvement of the production performances and feed conversion in all the experimental groups, compared to the control.
\end{abstract}

Keywords: intestinal villi, microvilli, laying quails, organic Selenium, Sel-Plex, Bio-Mos, Actigen

\section{INTRODUCTION}

Prebiotics are substances of organic or inorganic origin, both natural and synthesized that have the purpose of promoting the development and multiplying of prebiotic microorganisms in the digestive tract, thus contributing to a good health status and to the increase of the productive performances (Şara and Bențea, 2012). Prebiotics also enhances the nutrient absorption, of the macro an microelements, through the intestinal wall (Pop, 2006; Chen et al., 2004), subsequently increasing their availability for the maintenance and regenerative needs of the organisms and also for reproduction.

Bio-Mos and Actigen are oligosaccharides based prebiotics, manufactured by Alltech ${ }^{\circledR}$, by fermenting sugars using the Saccharomyches cerevisiae yeast.

It has been studied that the use of some oligosaccharides represents a method of manipulating 
the intestinal microbiota and prevent the on setting of potentially pathogen bacteria (Gibson et al., 2003) or to stimulate the absorption of minerals, specially Calcium and Magnesium (Roberfroid et al., 2000).

Bio-Mos and Actigen belong to the mannanoligosaccharides category, derivates of the mannans found on the cell surface, that act as high affinity binders thus offering competitive attaching sites for certain categories of bacteria (i.e Escherichia coli and Salmonella sp.). The Gramnegative bacteria attach themselves to the MOS instead of attaching to the epithelial cells of the intestine, thus transiting the intestine without colonizing it (Şara, 2006).

Several researches carried out worldwide indicate that the Bio-Mos or Actigen treatment positively influences the performances of broilers and laying poultry, regarding both quantity and quality of production, due to the curative properties that the two substances have on an intestinal level, by boosting the immune system and maintaining the health status.

Yang et al. (2007), by administering Bio-Mos $(2 \mathrm{~g} / \mathrm{kg})$ in chicken infected with E. coli, observed a significant reduction of tissue associated coliforms in the first week, compared to the control group. Loddi et al. (2004), administering Bio-Mos on broiler chickens reported the improvement of the feed conversion ratio and an increase of villi height. Janjeeiae et al. (2007), Gracia et al. (2004) and Dimovelis et al. (2004), administering BioMos to poultry reported an improvement of the feed conversion and a subsequent increase of production.

Gernat (2011), administering Actigen in broiler chickens reported superior results compared to the control group, the use of Actigen leading to an improvement of the FCR, reduced intestinal lesions and an enhanced immune system. Olejniczak and Nollet (2011), Haese et al. (2011), administering Actigen on broiler chickens noted a superior weight gain, a lower feed consumption and FCR and the decrease of mortality.

Sel-Plex, or organic Selenium, is manufactured by Alltech $\AA$ and is obtained from a strain of Saccharomyches cerevisae, being the first form of organic Selenium approved by the European Union.

Organic Selenium (Se-Met- selenomethionine) is actively absorbed in the intestine as an amino- acid participating in the same processes as methionine. The chemical similarities between selenomethionine and methionine allow the body to use them alternatively in protein synthesis. Thus, the formation of Selenium deposits in the organism can take place (especially in muscle tissue), reserves that are later used in times of stress, when the Selenium requirements are growing and the feed consumption diminishes.

Researches carried out worldwide showed that the use of Sel-Plex determined the improvement of the productive performances in poultry while decreasing the mortality rates.

Pan et al. (2004) and Stanley et al. (2004), after administering organic Selenium (Sel-Plex) on laying hens, reported improvements of the body weight, feed conversion, egg production and egg weight. Neylor et al. (2000) used diets containing organic Selenium and found that by increasing the Selenium percent in feeds, the feed efficiency is significantly improved. The positive effects of SelPlex on the FCR were also confirmed by Edens et al. (2001).

The major benefit of using Sel-Plex in chicken meat production includes the improvement of weight, FCR, the strengthening of the immune system and the decrease of mortality (Anciuti et al., 2004; Edens and Gowdy, 2004)

\section{MATERIALS AND METHODS}

The research was carried out on 132 laying quails, randomly assigned to 4 experimental groups, 33 birds / group, over a period of 26 weeks (02.06.2012 - 30.11.2012).

The birds were housed at the experimental location 1 week before the start of the laying period and one week prior to the beginning of the experiment, when the birds were 35 days old. This period allowed the bird a period of transition to the new environment and to the feeding regime and to avoid a delay of the laying period caused by the transport-induced stress.

The 4 groups ( 1 control, and 3 experimental groups) were housed in special cages designed for laying quails (dimensions being Lxlxh $=90 \times 50 \times 25$ $\mathrm{cm}$ ); the cages were positioned at the same height, had the same environmental conditions and received the same care throughout the experiment.

Water and feeds were constantly available for all groups. The combined fodder used in this experiment had the following composition: corn 
$37.5 \%$, wheat $10 \%$, soy bean meal $24 \%$, sun flower meal $13 \%$, corn gluten $2.5 \%$, vegetable oil $2.8 \%$, calcium carbonate $7.5 \%$, mono-calcium phosphate $1.2 \%$, L-lysine $0.075 \%$, methionine $0.025 \%$, vitamin-mineral premix $1 \%$ and salt $(\mathrm{NaCl}) 0.4 \%$. This fodder was the base fodder that was administered to the control group and was later supplemented for the experimental groups as follows: group 1E-0.08\% Actigen, group 2E$0.12 \%$ Bio-Mos and group 3E-0.04\% Sel-Plex.

The environmental temperature was 23$24^{\circ} \mathrm{C}$ and was maintained using 2 ventilators and a heater connected to a temperature-dependant programmable power source.

In order to better understand the mechanisms that contribute to the improvement of the quantity and quality parameters in laying quails, histological test were carried out on 5 birds from each group to determine the height of the villi and microvilli representing the nutrient absorption area in the intestine. Also, during the experimental period, body mass evolution, laying intensity and feed conversion were also recorded.

\section{RESULTS AND DISCUSSION}

Even though, at the beginning of the experiment, all the groups has the same initial weight, at the middle and at the end of the experimental period, significant differences were recorded between the experimental groups and the control group, regarding the body mass (Tab. 1). At the middle of the experiment, a mean body weight of $261.87 \pm 5.75 \mathrm{~g}$ was recorded in group $1 \mathrm{E}$, $262.12 \pm 7.39 \mathrm{~g}$ in group $2 \mathrm{E}$ and $263.06 \pm 6.33 \mathrm{~g}$ in group 3E, compared to the control group, were a mean body weight of $250.65 \pm 6.02 \mathrm{~g}$ was recorded.

At the end of the experimental period, the control group had almost the same body weight that was recorded at the middle of the

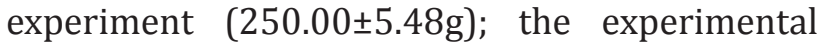
groups continued to accumulate body mass, the recorded values being of $281.43 \pm 5.27 \mathrm{~g}$ in group $1 \mathrm{E}, 267.81 \pm 6.42 \mathrm{~g}$ in group $2 \mathrm{E}$ and $285.06 \pm 5.22 \mathrm{~g}$ in group L3E. Significant differences have been recorded between groups $2 \mathrm{E}$ and the control group regarding the body mass recorded at the end of the experimental period; the differences recorded between groups $1 \mathrm{E}, 3 \mathrm{E}$ and the control group were very significant.

As can be seen in Table 2 the recorded values regarding the laying intensity indicate an improvement in the experimental groups (1E $-80.78 \pm 2.73,2 \mathrm{E}-78.46 \pm 2.89$ and $3 \mathrm{E}-83.62 \pm 2.76$ ) compared to the control group $(70.17 \pm 2.17)$. Group 1E (that received Actigen) had a 15.12\% ( $p<0.05$-significant) increase compared to the control group, group 2E (Bio-Mos) 11.81\% ( $p<0.05$-significant) increase and group 3E (SelPlex) had 19.16\% ( $\mathrm{p}<0.01$-distinctly significant) increase, compared to the control group.

Regarding the feed conversion ratio and the average feed consumption/egg, the recorded differences were distinctly significant (L2E-p<0.01) and very significant (L1E and L3E-p $<0.001$ ) in favor of the experimental groups. The quails from the experimental groups had a lower consumption of fodder/egg $(35.77 \pm 1.10 \mathrm{~g}$ in group $1 \mathrm{E}, 36.87 \pm 1.17 \mathrm{~g}$ in group $2 \mathrm{E}$ and

Tab. 1. Body weight of quails at the middle and at the end of the experimental period.

\begin{tabular}{|c|c|c|c|c|c|}
\hline Issue & & $\begin{array}{l}\text { Control } \\
\text { group }\end{array}$ & $\begin{array}{l}\text { Group 1E } \\
\text { (Actigen) }\end{array}$ & $\begin{array}{l}\text { Group 2E } \\
\text { (Bio-Mos) } \\
\end{array}$ & $\begin{array}{l}\text { Group 3E } \\
\text { (Sel-Plex) }\end{array}$ \\
\hline $\mathrm{N}$ & & 33 & 33 & 33 & 33 \\
\hline \multirow{2}{*}{$\begin{array}{l}\text { Initial weight (g) } \\
\text { (3 weeks of age) }\end{array}$} & $\mathrm{X} \pm \mathrm{xs}$ & $183.15 \pm 3.35$ & $183.24 \pm 3.45$ & $182.42 \pm 3.56$ & $183.27 \pm 5.18$ \\
\hline & $\mathrm{V} \%$ & 10.54 & 10.81 & 11.23 & 16.26 \\
\hline $\mathrm{N}$ & & 29 & 32 & 31 & 33 \\
\hline \multirow{2}{*}{$\begin{array}{l}\text { Weight - middle of } \\
\text { experiment (g) } \\
(19 \text { weeks of age) }\end{array}$} & $\mathrm{X} \pm \mathrm{xs}$ & $250.65 \pm 6.02$ & $261.87 \pm 5.75$ & $262.12 \pm 7.39$ & $263.06 \pm 6.33$ \\
\hline & V\% & 12.93 & 12.42 & 15.70 & 13.83 \\
\hline $\mathrm{N}$ & & 28 & 32 & 31 & 33 \\
\hline \multirow{2}{*}{$\begin{array}{l}\text { Final weight (g) } \\
\text { (32 weeks of age) }\end{array}$} & $\mathrm{X} \pm \mathrm{xs}$ & $250.00 \pm 5.48$ & $281.43 \pm 5.27^{* * *}$ & $267,81 \pm 6.42 *$ & $285.06 \pm 5.22$ *** \\
\hline & V\% & 11.60 & 10.59 & 13.36 & 10.52 \\
\hline
\end{tabular}


Tab. 2. The mean values of the production and consumption indices in laying quails throughout the experimental period.

\begin{tabular}{cccccc}
\hline \multirow{2}{*}{ Issue } & & \multicolumn{5}{c}{ Experimental groups } \\
\cline { 2 - 6 } & & $\mathrm{M}$ & $\begin{array}{c}\text { Group 1E } \\
\text { (Actigen) }\end{array}$ & $\begin{array}{c}\text { Group 2E } \\
\text { (Bio-Mos) }\end{array}$ & $\begin{array}{c}\text { Group 3E } \\
\text { (Sel-Plex) }\end{array}$ \\
\hline \multirow{2}{*}{ Total weight gain } & $\begin{array}{c}\mathrm{g} / 26 \\
\text { weeks. }\end{array}$ & 66.82 & 98.19 & 85.39 & 101.79 \\
\cline { 2 - 6 } & $\%$ & 100 & 146.94 & 127.79 & 152.33 \\
\hline $\begin{array}{c}\text { Laying intensity } \\
(\%)\end{array}$ & Absolute & $70.17 \pm 2.17$ & $80.78 \pm 2.73^{*}$ & $78.46 \pm 2.89^{*}$ & $83.62 \pm 2.76^{* *}$ \\
\cline { 2 - 6 } & Relative & 100.00 & 115.12 & 111.81 & 119,16 \\
\hline $\begin{array}{c}\text { Feed conversion } \\
\text { ratio/ egg }\end{array}$ & $\mathrm{g}$ & $43.09 \pm 1.19$ & $35.77 \pm 1.10^{* * *}$ & $36.87 \pm 1.17^{* *}$ & $34.19 \pm 1.30^{* * *}$ \\
\cline { 2 - 6 } & $\%$ & 100 & 83.01 & 85.57 & 79.35 \\
\hline *-p $<0.05-$ significant; $^{* *}$ - p<0.01- distinctly significant; ${ }^{* * *}$ - p<0.001- very significant.
\end{tabular}

Tab. 3. The height of the intestinal villi in laying quails (values are average of 10 determination/ sample, $\mu \mathrm{m})$.

\begin{tabular}{|c|c|c|c|c|}
\hline & Control group & & Experimental group & \\
\hline Samples & $\mathbf{M}$ & Group 1E & Group 2E & Group 3E \\
\hline $\mathbf{n}$ & 5 & 5 & 5 & 5 \\
\hline $\mathrm{X} \pm \mathrm{Xs}$ & $1101.38 \pm 24.39$ & $1391.66 \pm 29.20 * *$ & $1627.45 \pm 60.69 * * *$ & $1511.46 \pm 46.89 * * *$ \\
\hline $\mathrm{V} \%$ & 4.95 & 4.69 & 8.34 & 6.94 \\
\hline
\end{tabular}

Tab. 4. The height of the intestinal microvilli in laying quails (values are average of 10 determination/ sample, $\mu \mathrm{m})$.

\begin{tabular}{ccccc}
\hline & Control group & \multicolumn{3}{c}{ Experimental groups } \\
\hline Probe & $\mathbf{M}$ & Group 1E & Group 2E & Group 3E \\
\hline $\mathbf{n}$ & 5 & 5 & 5 & 5 \\
\hline $\mathbf{X} \pm \mathbf{x s}$ & $2.70 \pm 0.13$ & $3.07 \pm 0.18$ & $3.20 \pm 0.24$ & $3.18 \pm 0.20$ \\
\hline $\mathbf{V} \%$ & 10.54 & 13.43 & 16.78 & 14.16 \\
\hline
\end{tabular}

V\%- variability; X- mean; xs-standard deviation; $n$ - number of samples;

L1E-1 ${ }^{\text {st }}$ experimental group; L2E-2 $2^{\text {nd }}$ experimental group; L3E- $3^{\text {rd }}$ experimental group.

$34.19 \pm 1.30 \mathrm{~g}$ in group $3 \mathrm{E}$ ) compared to the control group $(43.09 \pm 1.19 \mathrm{~g})$. The feed consumption for an egg was $16.99 \%$ lower in the experimental group $1 \mathrm{E}(0.08 \%$ Actigen) compared to the control group; $14.43 \%$ lower in the experimental group 2E (0.12\% Bio-Mos) and $20.65 \%$ lower in the experimental group 3E (0.04\% Sel-Plex).

The results regarding the improvement of the production and consumption indices of laying poultry, by dietary supplementation using organic Selenium (Sel-Plex) are also confirmed by Stanley et al. (2004), Pan et al. (2004), Şara et al. (2008); the positive effects of Bio-Mos are also confirmed by Janjeeiae et al. (2007), Kocher et al. (2005) and the favorable effects of Actigen have also been described by Lea et al. (2011) and Munyaka et al. (2011).

To underline the effects the prebiotics (BioMos and Actigen) and the organic Selenium (SelPlex) have at an intestinal level and subsequently on the production and consumption indices, histological investigation have been carried out, consisting of determinations of the villi and microvilli height. Table 3 shows the data regarding 
the height of the intestinal villi at the end of the experimental period, in the quails from all the experimental groups, their aspect being shown in Figure 1.

The measurements carried out on the height of the intestinal villi of quails show increases of the villi structures in all the experimental groups $(1391.66 \pm 29.20 \mu \mathrm{m}$ in group $1 \mathrm{E}, 1627.45 \pm 60.69 \mu \mathrm{m}$ in group $2 \mathrm{E}$ and $1511.46 \pm 46.89 \mu \mathrm{m}$ in group $3 \mathrm{E}$ ) compared to the control group $(1101.38 \pm 24.39 \mu \mathrm{m})$; the result recorded in the experimental groups were $26.35 \%$, $47.76 \%$ and $37.23 \%$ higher than the one recorded in the control group. Table 4 presents the values regarding the height of the intestinal microvilli in laying quails, their aspect being shown in Figure 2. Group 1E (Actigen) had a lower mean value of the microvilli height $(3.07 \pm 0.18 \mu \mathrm{m}) 13.7 \%$ higher than the values recorded in the control group $(2.70 \pm 0.13 \mu \mathrm{m})$. Group 2E (Bio-Mos) had a mean value of $3.20 \pm 0.24 \mu \mathrm{m}, 18.51 \%$ higher than the control group; group 3E (Sel-Plex) had a mean value of $3.18 \pm 0.20 \mu \mathrm{m}, 17.77 \%$ higher than the control group.

The data recorded from the histological investigations confirm the positive influence of the used additives (Actigen, Bio-Mos, Sel-Plex) on he intestinal morphology, regarding the nutrient absorption area. Thus, all the recorded results regarding production that were recorded in the experimental groups can be explained by the improved and accelerated nutrient absorption. The results found by the histological investigations are confirmed by the works of other authors that researched the influence of these additives on poultry. Bonos et al. $(2010,2011)$ found that the use of mannan-oligosaccharides and prebiotics (MOS) on laying quails can positively influence the intestinal function by improving the height, uniformity and integrity of the intestinal villi. Loddi et al. (2004) investigated the effects of BioMos on performances and intestinal morphology in broiler chickens and reported that the use of Bio-Mos improved the feed conversion ration at the same time increasing the height and width of the intestinal villi. Papazyan and Surai (2004) found that the dietary supplementation using SelPlex can improve the intestinal morphology and subsequently the nutrient absorption area, results also confirmed by Dibner (2000).

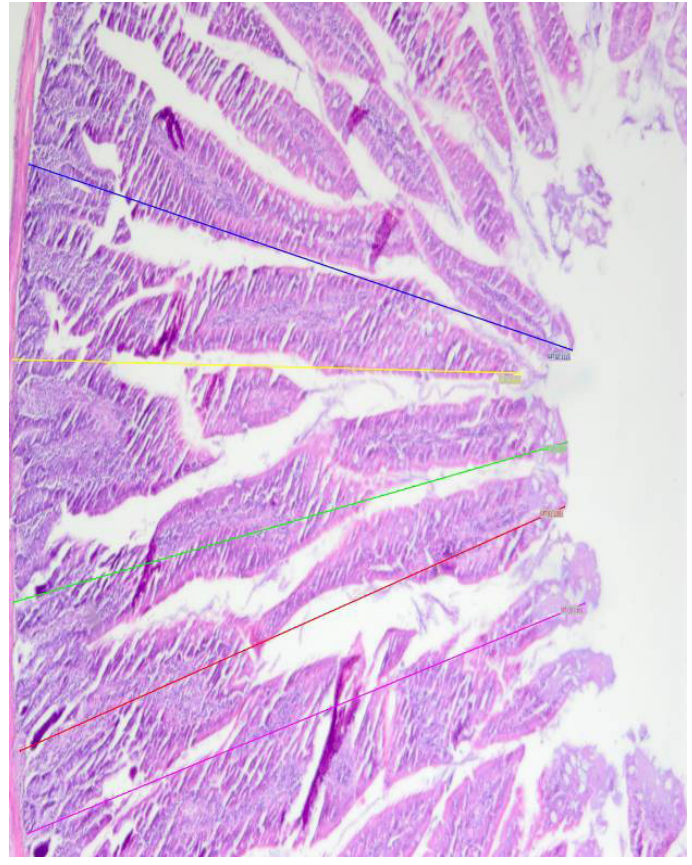

Fig. 1. Intestinal villi in quail (Olympus BX51) (Hematoxylin Eosin, 4x magnification)

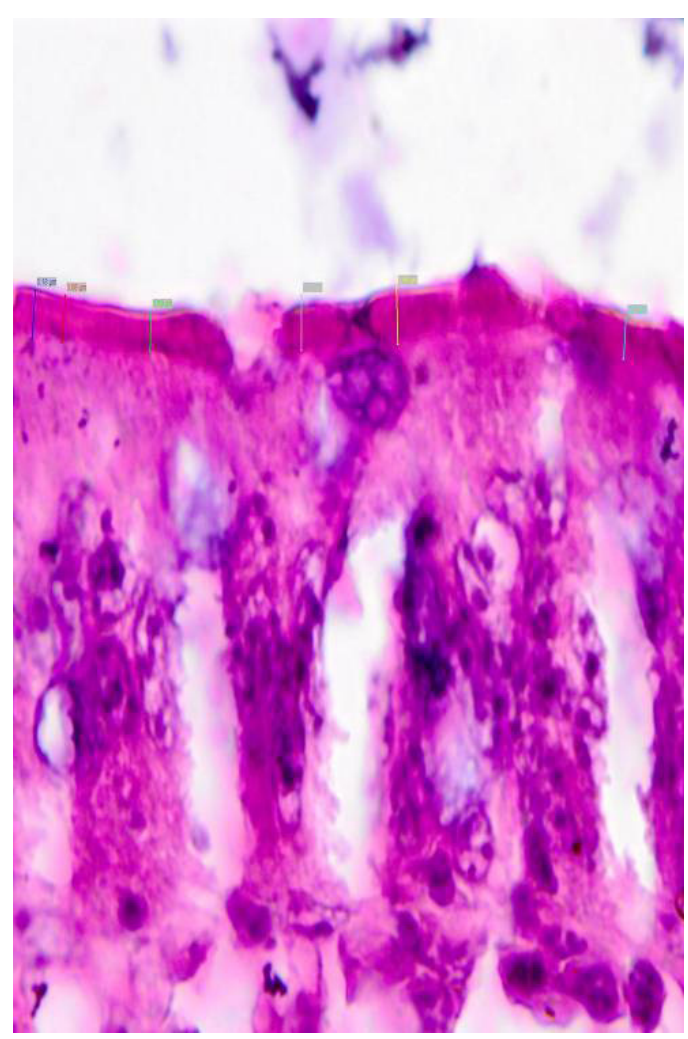

Fig 2. Intestinal microvilli in quails (Hematoxylin Eosin, 100x magnification) 


\section{CONCLUSION}

The histological investigations carried out at the end of the experimental period on laying quails showed that the use of prebiotics (Actigen and BioMos) and organic Selenium (Sel-Plex) led to a better development of the intestinal villi and microvilli thus increasing the nutrient absorption area leading to an improved nutrient assimilation that translated to superior body weight, productions and feed conversions in all the experimental groups, compared to the control group.

Based on the results recorded, we recommend the use of Actigen and Bio-Mos prebiotics and SelPlex organic Selenium in laying quails.

\section{REFERENCES}

1. Anciuti MA, Rutz E, Da Silva LA, Cosenza RC and Da Silva RG (2004). Effect of replacement of dietary inorganic by organic selenium (Sel-Plex) on performance of broilers. Nutritional Biotechnology in the Feed and Food Industry. Proceedings of the $20^{\text {th }}$ Annual Symposium (Suppl. 1), Lexington, Kentucky, USA, 14.

2. Bonos E, E Christaki, P Florou-Paneri (2010). Performance and carcass characteristics of Japanese quail as affected by sex or mannan oligosaccharides and calcium propionate, S, Afr. J. Anim. Sci. 40 (2010), 173-184.

3. Bonos E, E Christaki, P Florou-Paneri (2011). Effects of dietary mannan oligosaccharides and calcium formate on performance and egg quality of japanes quail (Coturnix Japonica). Journal of Food and Science and Engineering 1 289-296.

4. Chen YC and TC Chen (2004). Mineral utilization in Layers as Influenced by Dietary Oligofructose and Inulin, Intl. J. of Poult. Sci. 3 (7): 442-445.

5. Chen YC, C Nakthong and TC Chen (2005). Improvement of laying hen performance by dietary prebiotic chicory oligofructose and inulin. Int.J. Poult. Sci., 4:103-108.

6. Dibner J (2000). Early nutritionin young poultry. In:Recent Advances in Animal Nutrition, Edited by Garnsworthy, P.C. and Wiseman, J., Nottingham University Press, Nottingham, 73-88.

7. Dimovelis P, Christaki E, Tserveni-Goussi A, Spais AB (2004). Performance of layer hens fed a diet with mannanoligosaccharides from Sacharomyces cerevisiae (Bio-Mos). In 'World Poultry Congress'. Istanbul, Turkey, 1-4. (WPSA).

8. Edens FW (2001). Involvement of Sel-Plex in physiological stability and performance of broiler chickens. In: Biotechnology in the Feed industry. Proceedings of $17^{\text {th }}$ Alltech's Annual Symposium, Edited by Lyons TP and Jacques KA Nottingham University Press, UK, 349-376.

9. Edens FW and Gowdy KM (2004). Field results with broilers fed selenium yeast In: Nutritional Biotechnology in the Feed and Food Industry. Proceedings of the $20^{\text {th }}$ Annual Symposium (Suppl. 1), Lexington, Kentucky USA, 32.

10. Gernat A., (2011), Actigen ${ }^{\mathrm{TM}}$ and $\mathrm{Zn}$ bacitracin: Comparative effects on performance, intestinal integrity and immunity of broilers, $27^{\text {th }}$ International Symposium "Science and Technology in the Feed Industry".

11. Gibson GR, Probert H and Roberfroid MB (2003). Dietary modulation of the human colonie microbiota: Revisiting the concept of prebiotics. J. Nutr., 125: 1401-1412.

12. Garcia M, Cachaldora P, Tucker LA, Baucells F, Medel P (2004). Effect of mannan oligosaccharides supplementation to laying hen diets. Poultry Science 83, 397.

13. Janjeeiae Z, Music S, Kos I, Esegoviae I (2007). Hrănirea restrictivă cu Bio-Mos suplimentat la puii broileri, Proceedings of Alltech's $23^{\text {rd }}$ Annual Szmposium, Faculty of Agriculture, University of Zagreb, Croatia.

14. Kocher A, Garcia P, Tucker LA (2005). Effects of Bio-Mos for laying hens 20-52 weeks under commercial conditions. World Poultry Science Association, 15th European Symposium on Poultry Nutrition, Balatonfured, Hungary.

15. Lea HK, Kay L and EJ Burton (2011). Performance and gut health of poultry in the post-antibiotic era when feeding a novel yeast cell wall component, $27^{\text {th }}$ International Symposium "Science and Technology in the Feed Industry".

16. Loddi MM, VMB Moraes, LSO Nakaghi, FM Tucci, MI Hannas and J Ariki (2004). Proceedings of the 20th Annual Symposium (Supplement 1).

17. Munyaka P, Echeverry HM, Yitbarek A, Einarson M, Sharif S, Guenter W, House JD, Rodriguez-Lecompte JC (2011). Toll-like receptor and cytokine profile of chickens supplemented with Actigen ${ }^{\mathrm{TM}}, 27^{\text {th }}$ International Symposium "Science and Technology in the Feed Industry".

18. Neylor AJ, Choct M and Jacques KA (2000). Effects of selenium source and level on performance and meat quality in male broilers. Poultry Science 79 (Suppl) 117.

19. Olejniczak Renata and Nollet L (2011). Evaluation of the effectiveness of Actige ${ }^{\mathrm{TM}}$ as a growth promoter in broilers, $27^{\text {th }}$ International Symposium "Science and Technology in the Feed Industry".

20. Pan EA, F Rutz, NJL Dionello, MA Anciuti and Da Silva (2004). Organoselenium effect on the performance of laying hens, Proceedings of the $20^{\text {th }}$ Annual Symposium (Supplement 1).

21. Pan EA, Rutz F, Dionello NJL, Anciuti MA and Da Silva RR (2004). Performance of brown egg layers fed diets containing organic selenium (Sel-Plex). Nutritional Biotechnology in the Feed and Food Industry. Proceedings of the $20^{\text {th }}$ Annual Symp. (Suppl. 1), Lexington, Kentucky, USA, 18.

22. Papazyan TT and P F Surai (2004). Effect of organic selenium supplementation in chickens in terms of their growth and development. Proceedings of the $20^{\text {th }}$ Annual Symposium (Supplement 1).

23. Pop IM (2006). Aditivi furajeri. Ed. TipoMoldova. Iaşi.

24. Roberfroid MB (2000). Prebiotics and probiotics: are they functional foods? Am. J. Clin. Nutr., 71 (Suppl): 162S-168S.

25. Stanley VG, V Yancy, C Gray, FW Krueger and AE Sefton (2004). Organoselenium effect on the performance of laying hens, Proceedings of the $20^{\text {th }}$ Annual Symposium (Supplement 1).

26. Șara A, M Bentea (2012). Nutrețurile, caracteristici nutritive și utilizare, Ed. Risoprint, Cluj-Napoca, 150-153. 
27. Sara A, Antonia Odagiu, M Bențea, L Pantă, Mariana Dinea (2006). Efectele utilizării produsului bio-mos în hrana găinilor ouătoare în ultima fază de ouat. Simpozion Ştiințific Internațional „Calitate şi performanță de nivel european în producția animală”. Lucrări Ştiințifice Zoothenie şi Biotehnologii Timişoara, vol. 39 ISSN 12215287, 353- 357.

28. Sara A, M Bențea, Antonia Odagiu, L Pantă (2008). Effects of the organic selenium (Sel- Plex) administered in laying hens' feed in second laying phase on production performances and the eggs quality. Buletin USAMVAnimal Science and Biotechnologies, 65 (1-2)/2008 ISSN 1843- 5262, Electronic ISSN 1843- 536X, 83- 87.

29. Yang Y, Iji PA and Choct M (2007). Efectul Bio-Mos-ului în ceea ce priveşte dinamica dinamica bacteriilor mucoasei asociată puilor broileri, Proceedings of Alltech's $23^{\text {rd }}$ Annual Szmposium, The University of New England, Australia. 